DOI: $10.14807 /$ ijmp.v10i4.755

\title{
ANALYSIS OF PUBLICATIONS OF A SCIENTIFIC PERIODIC: EVALUATION BY THE TOOL SPC
}

\author{
Paulo Cesar Chagas Rodrigues \\ Instituto Federal de Educação, Ciência e Tecnologia de São \\ Paulo (IFSP), Brazil \\ E-mail: paulo.rodrigues@ifsp.edu.br
}

Franco da Silveira Universidade Federal do Rio Grande do Sul, Brazil E-mail: franco.da.silveira@hotmail.com

Bruno Miranda dos Santos Universidade Federal do Rio Grande do Sul, Brazil

E-mail: brmiranda10@gmail.com

Filipe Molinar Universidade Regional Integrada do Alto Uruguai e Missões (URI), Brazil E-mail: fmacmec@gmail.com

Submission: 01/10/2019 Acceptt: 02/11/2019

\section{ABSTRACT}

The work consists of analyzing the historical evolution of an international scientific journal, which is characterized by publications via the web and the Open Journal System (OJS) software. In data collection it was necessary to use Google analytics between the years 2014 and 2017, based on the access / session variables and their respective averages. By means of Excel, a statistical analysis was performed based on Statistical Process Control (SPC). The research method selected was the case study, with data and information complemented by bibliographical and documentary research. As a result, the research identified that the international scientific journal presents mostly male users with Brazilian or foreign nationality. Moreover, in the stratification of the journal users by sex and titration it was possible to perceive that doctors are responsible for the greater number of records, both male and female. Finally, there is an increase in the number of views in the international scientific journal, thus confirming that there is a significant importance among academic researchers in seeking access to publications made available via the web. 
DOI: 10.14807/ijmp.v10i4.755

Keywords: SPC; Google Analytics; Open Journal System; scientific journal

\section{INTRODUCTION}

The attention of the scientific community is largely induced by the integration of the information of different subjects of objects, elements of publications and research methods (PAVLOVSKIY, 2017). Oliveira (2002) corroborates that communication is an indispensable element for the scientific activity to provide knowledge, since without it, there would be no science and could not add the individual efforts of members of scientific communities. In addition, it should be noted that knowledge must be shared and universities, research organizations, among others, must find a way to do so. Thus, databases can be a solution to promote the creation of value and scientific production (FIGUEIREDO; PEREIRA, 2017).

With the development of Information and Communication Technologies (ICT), it is possible to access most of the scientific literature through the internet (RAVISHANKAR, 2013, ASADI, et al., 2017). Thus, knowledge transfer happens in a correct and efficient manner (MONTOYA et al., 2018). The means by which scientific information is processed and, consequently, communication can include periodicals, theses, dissertations, reports, annals and proceedings of congresses, patents, among others. It emphasizes the role of journals, which are responsible for fostering the quality of research and help in the development of knowledge and information.

According to Ferreira and Caregnato (2008), there are magazines that migrate from the printed to the electronic format, from which the printed version ceases and only the electronic format is available, and those that are already born online. With emphasis on the electronic journal, some advantages are related, such as: i) the ever increasing number of users who can instantly read and access articles simultaneously; ii) coverage of the journal, which is no longer local and becomes global; and iii) minimization of time and costs with the electronic process (FERREIRA; CAREGNATO, 2008). According to Márdero Arellano, Ferreira and Caregnato (2005), electronic publishing systems have emerged, allowing for reduced time consuming and administrative costs.

Open Journal Systems (also known as Electronic Journaling System - OJS / SEER) is a software developed for the construction and management of an electronic periodical publication. This tool includes actions related to the automation of publishing 
activities of scientific journals. (IBICT, 2018). In this way, the article aims to analyze the historical evolution of an international scientific periodical, which is characterized by publications via the web and OJS software.

The study assumes relevance since the evaluation criteria used to designate budgets in federal and private research are generally based on scientificometric indicators retrieved through academic search engines, which include the number and quality of metric-based researchers' publications of journals and authors (MCNUTT, 2014). The article was structured in five different sections, in addition to this initial introduction. In section 2 is the context about the statistical process control adopted in the research and its main aspects. Section 3 presents the methodological approach used in the study. In section 4 the results are shown. Section 5 presents the research findings and proposals for future work. Finally, section 6 presents the references used in the research.

\section{STATISTICAL PROCESS CONTROL}

Giron, et al. (2013) Statistical Process Control (SPC) are procedures adopted to evaluate, maintain and improve quality standards in the various manufacturing stages. These process control procedures are designed to ensure quality economically. According to Fettback, Giron and Neto (2011), the statistical application in the control of productive processes, has been showing its efficiency. It also demonstrates whether the product is within a compliance degree or not, based on a pre-set parameter.

Montgomery (2004) argues that SPC can be understood as a statistical and engineering method used in measurement, monitoring, control and quality improvement processes. The SPC method is part of the development of statistical tools for sampling and statistical process control, oriented to process quality control, characterized by a preventive focus focused on the monitoring and control of the variables that may influence the final quality of the products (TOLEDO; BATALHA; AMARAL, 2000).

SPC can be considered as a simple tool and, at the same time, one of the most powerful quality control methodologies ever developed (LIMA, et al., 2006). SPC is a tool widely used by industries in different sectors of the economy at the international level, since it allows controlling product and process characteristics through the use of 
statistics as a methodology to analyze process limitations, guaranteeing excellent levels of quality (NOMELINI; FERREIRA; OLIVEIRA, 2009; VACCARO; MARTINS; MENEZES, 2011).

The SPC allows, through the application of statistical methods, the maintenance of a continuous improvement of quality and productivity in the productive processes (CARNEIRO NETO, 2003; MOREIRA, 2004; LIMA et al., 2006). The SPC tools aim to verify the performance of the process in the company, trying to analyze the trends of variations of this process, from data collected with the purpose of minimizing this variability (SANTOS et al., 2010). Kume (1985) states that statistical methods provide effective ways for the development of new technologies and quality control in manufacturing processes.

According to Giron et al. (2013), control charts are a quality technique that allows control of processes and products based on statistical analysis. Starting from the premise that every process presents variations and that, from certain variations, it is possible to determine parameters that inform us if the process is occurring within the expected limits or if there is some event that will put it out of control. The importance of statistical control charts is in detecting the occurrence of lack of control in the process, and its efficient use demonstrates its excellence in detecting and reducing variability, providing an increase in the percentage of products capable of satisfying the client's requirements (VILAS BOAS, 2005).

\section{METHOD OF RESEARCH}

The research can be classified as a case study, as the information was collected in an international scientific journal. According to Gil (2009) and Yin (2005), this type of research has the particularity of presenting the analysis of documentary and bibliographic data, in order to allow its comprehensive and detailed knowledge. The research is classified as exploratory, as it seeks to understand a phenomenon in its initial phase (as the application of the SPC in the analysis of access data during the years 2014 and 2017, identifying its particularities) and then explain its causes and consequences (GIL, 2009).

To describe the application of the SPC in the periodical in question, as well as its particularities, it is observed that this research can be considered as a descriptive study. According to Marconi and Lakatos (2009), they are research that seeks to 
systematically describe an area of interest or a phenomenon under analysis. In the figure is the methodological flow adopted in the research.

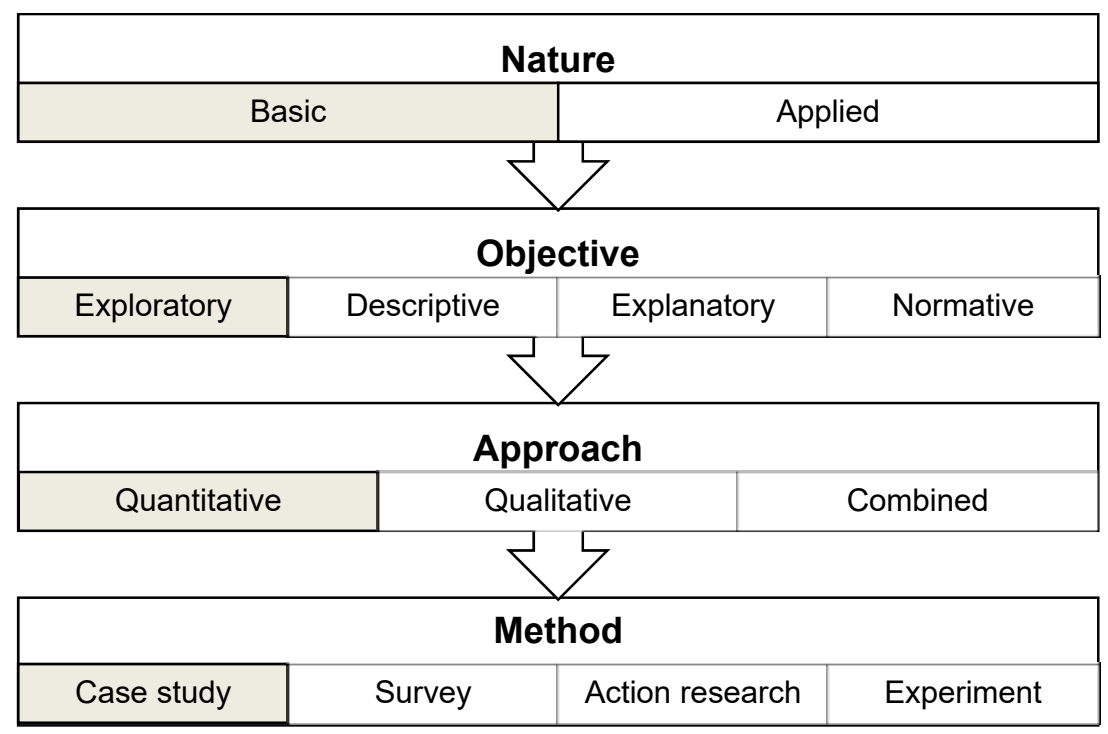

Figure 1: Methodology selected in the research. Source: Adapted from Miguel (2010).

The research on nature is basic because it consists in the accomplishment of a theoretical work, whose main purpose is related to the acquisition of new knowledge about the international scientific periodical (GIL, 2009; MIGUEL, 2010). Its approach is quantitative because it prioritizes to point numerically the frequency of the behaviors of a determined group of researchers that access the platform on the web (MIGUEL, 2010).

\section{RESULTS AND DISCUSSIONS}

The case study was conducted in an international journal, which was created in 2010 and currently has approximately 2.396 users, being accessed by 200 countries in 5.000 cities. The journal attends the areas of administration, accounting sciences, tourism, engineering, among other areas. Table 1 shows the distribution of newspaper users according to their gender (gender) and nationality (Brazilian or foreign).

Table 1: Distribution of users.

\begin{tabular}{|c|c|c|c|c|c|}
\hline & Male & Female & Others & Total & $\%$ \\
\hline Brazilians & 468 & 182 & 4 & 654 & 26,24 \\
\hline International & 1.312 & 525 & 1 & 1.838 & 73,76 \\
\hline Total & 1.780 & 707 & 5 & 2.492 & 100 \\
\hline
\end{tabular}

Table 2 presents a stratification of the users of the journal by sex and titration, so that the user profile that accesses and registers can be observed. It is noted that 
DOI: 10.14807/ijmp.v10i4.755

users are classified as doctors in their entirety, both male and female. In addition, the male gender has a greater participation in the stratification of users $(71.4 \%)$.

Table 2: User stratification.

\begin{tabular}{lcccccccccc}
\hline \multicolumn{10}{c}{ Titration } \\
\hline Genre & Dr./Ph.D. & MSc. & Dr. & MSc. & Esp. & Prof. & Estud. & Others & Total & $\%$ \\
\hline Male & 1023 & 251 & 239 & 59 & 34 & 22 & 53 & 99 & 1.780 & 71,57 \\
\hline Female & 372 & 114 & 122 & 18 & 13 & 3 & 42 & 23 & 707 & 28,43 \\
\hline Total & $\mathbf{1 . 3 9 5}$ & $\mathbf{3 6 5}$ & $\mathbf{3 6 1}$ & $\mathbf{7 7}$ & $\mathbf{4 7}$ & $\mathbf{2 5}$ & $\mathbf{9 5}$ & $\mathbf{1 2 2}$ & $\mathbf{2 . 4 8 7}$ & $\mathbf{1 0 0}$ \\
\hline \multicolumn{10}{c}{ Source: Authors (2019) }
\end{tabular}

According to the Publish or Perish application, the number of articles published is 358 and a total of 404 citations, making approximately 50.50 citations per year, thereby obtaining an index $\mathrm{h}$ of 9 and an index $\mathrm{g}$ of 12 , hl- normal of value 6 , and the factor hl-annual of value 0.75 .

According to Araújo and Sardinha (2011), the h-index consists of the number of published articles that received citations greater than or equal to that number and can be applied to individual researchers or groups of researchers, as well as journals. With a conSPCtualization very close to the central tendency measure known as the median, the $\mathrm{h}$-index is not influenced by extremes, as for example, it happens with the average of citations per published article.

Table 3 shows the total number of sessions or accesses per month, between the years 2014 and 2018, showing monthly and annual growth. As the journal only acSPCts articles in English, it is verified that there is an international scope and that it makes possible a greater relevance in the scientific community. Figures 2, 3, 4 and 5 present the control charts, which show how the number of accesses / sessions in the following four years has increased, highlighting the months in which there was a considerable variation, either for more or less, in relation to the average and the median. It can also be observed in Table 3, the average daily accesses and their variation that in 2014 was 31.45 to 68.40 , and it can be observed that in 2018 the lowest average daily access was 110.71 and the highest was 212.19 . The daily average was calculated based on the total number of accesses / sessions in the month, divided by the number of days. It should be noted that the month of February of the year 2016 had 29 days. 
INDEPENDENT JOURNAL OF MANAGEMENT \& PRODUCTION (IJM\&P)

http://www.ijmp.jor.br

v. 10, n. 4, Special Edition IFLOG 2018

ISSN: 2236-269X

DOI: 10.14807/ijmp.v10i4.755

Table 3: Number of sessions per month and year.

\begin{tabular}{lcccccccccc}
\hline Year & \multicolumn{2}{c}{$\mathbf{2 0 1 4}$} & \multicolumn{2}{c}{$\mathbf{2 0 1 5}$} & $\mathbf{2 0 1 6}$ & $\mathbf{2 0 1 7}$ & \multicolumn{2}{c}{$\mathbf{2 0 1 8}$} \\
\hline Month & Sessions & Average & Sessions & Average & Sessions & Average & Sessions & Average & Sessions & Average \\
\hline January & 1.573 & 50,74 & 1.368 & 44,13 & 2.329 & 75,13 & 1.686 & 54,39 & 3.432 & 110,71 \\
\hline February & 1.635 & 58,39 & 1.390 & 49,64 & 3.053 & 109,04 & 1.999 & 68,93 & 3.247 & 115,96 \\
\hline March & 1.626 & 52,45 & 2.682 & 86,52 & 3.934 & 126,90 & 2.372 & 76,52 & 5.018 & 161,87 \\
\hline April & 2.052 & 68,40 & 2.041 & 68,03 & 2.998 & 99,93 & 2.091 & 69,70 & 4.700 & 156,67 \\
\hline May & 1.608 & 51,87 & 2.298 & 74,13 & 3.031 & 97,77 & 2.002 & 64,58 & 4.396 & 141,81 \\
\hline June & 1.189 & 39,63 & 1.962 & 65,40 & 3.246 & 108,20 & 2.222 & 74,07 & 3.913 & 130,43 \\
\hline July & 975 & 31,45 & 1.478 & 47,68 & 3.088 & 99,61 & 2.006 & 64,71 & 4.161 & 134,23 \\
\hline August & 1.050 & 33,87 & 1.858 & 59,94 & 2.820 & 90,97 & 1.991 & 64,23 & 4.232 & 136,52 \\
\hline September & 1.435 & 47,83 & 1.877 & 62,57 & 3.163 & 105,43 & 2.478 & 82,60 & 5.670 & 189,00 \\
\hline October & 1.219 & 39,32 & 2.155 & 69,52 & 3.555 & 114,68 & 2.294 & 74,00 & 6.578 & 212,19 \\
\hline November & 1.512 & 50,40 & 1.771 & 59,03 & 2.530 & 84,33 & 2.867 & 95,57 & 6.276 & 209,20 \\
\hline December & 1.564 & 50,45 & 2.137 & 68,94 & 3.424 & 110,45 & 2.647 & 85,39 & 5.534 & 178,52 \\
\hline Total & $\mathbf{1 7 . 4 3 8}$ & & $\mathbf{2 3 . 0 1 7}$ & & $\mathbf{3 7 . 1 7 1}$ & & $\mathbf{2 6 . 6 5 5}$ & & $\mathbf{5 7 . 1 5 7}$ & \\
\hline
\end{tabular}

Source: Authors (2019)

Table 4 shows the increasing variation of the average between the years 2014 and 2018. An increase in the value between the years 2014 and 2015 of 465 points can be observed. In the comparison between the years 2015 and 2016 there was a smaller but still significant growth of 303 points and between the years 2016 and 2017 the growth was 877 points and the comparison between the years 2017 and 2018 the growth was of 1,437 points, allowing us to observe that the Journal grew quite significantly compared to the previous years.

It can be observed that the median, standard deviation, lower and upper limit and amplitude variables also grow interestingly between the years 2014 and 2017, but in 2018, this growth was relatively accentuated. It can be observed that the amplitude almost tripled compared to 2017.

Table 4: Results referring to mean, median, standard deviation, LIC and LSC.

\begin{tabular}{lrrrrr}
\hline Year & $\mathbf{2 0 1 4}$ & $\mathbf{2 0 1 5}$ & $\mathbf{2 0 1 6}$ & $\mathbf{2 0 1 7}$ & $\mathbf{2 0 1 8}$ \\
\hline Average & 1.453 & 1.918 & 2.221 & 3.098 & 4.535 \\
\hline Medium & 1.538 & 1.920 & 2.157 & 3.071 & 4.314 \\
\hline Standard deviation & 300,265 & 387,423 & 329,251 & 431,491 & $1.013,028$ \\
\hline LIC & 552 & 756 & 1.233 & 1.803 & 1.496 \\
\hline LSC & 2.354 & 3.080 & 3.209 & 4.392 & 7.574 \\
\hline Amplitude & 1.802 & 2.324 & 1.976 & 2.589 & 6.078 \\
\hline \multicolumn{5}{l}{ Source: Authors $(2019)$}
\end{tabular}

Figure 2 shows the control chart, with respect to upper and lower limits, as well as the mean and median and number of sessions. It is noted that in the year of 2014 the months of April, July and August have distanced themselves to more or less in relation to the average and median. 


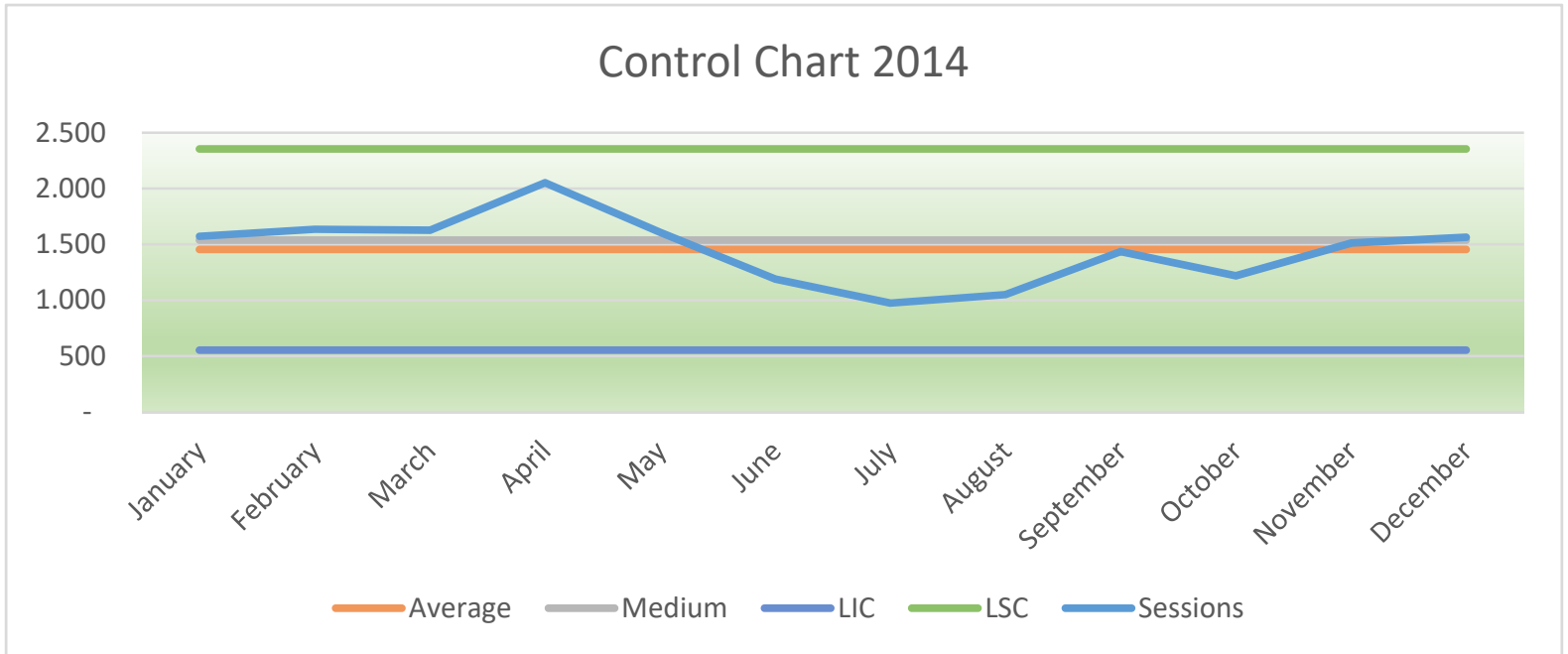

Figure 2: Control Graph of the sessions / accesses of the year 2014. Source: Authors (2019).

Figure 3 shows the behavior regarding the accesses / sessions that the journal obtained during the year 2015. It can be observed in the control chart that the months of January, February, March and July were far from the values referring to the mean and median Thus, the mean and median values were very close, but the median was higher.

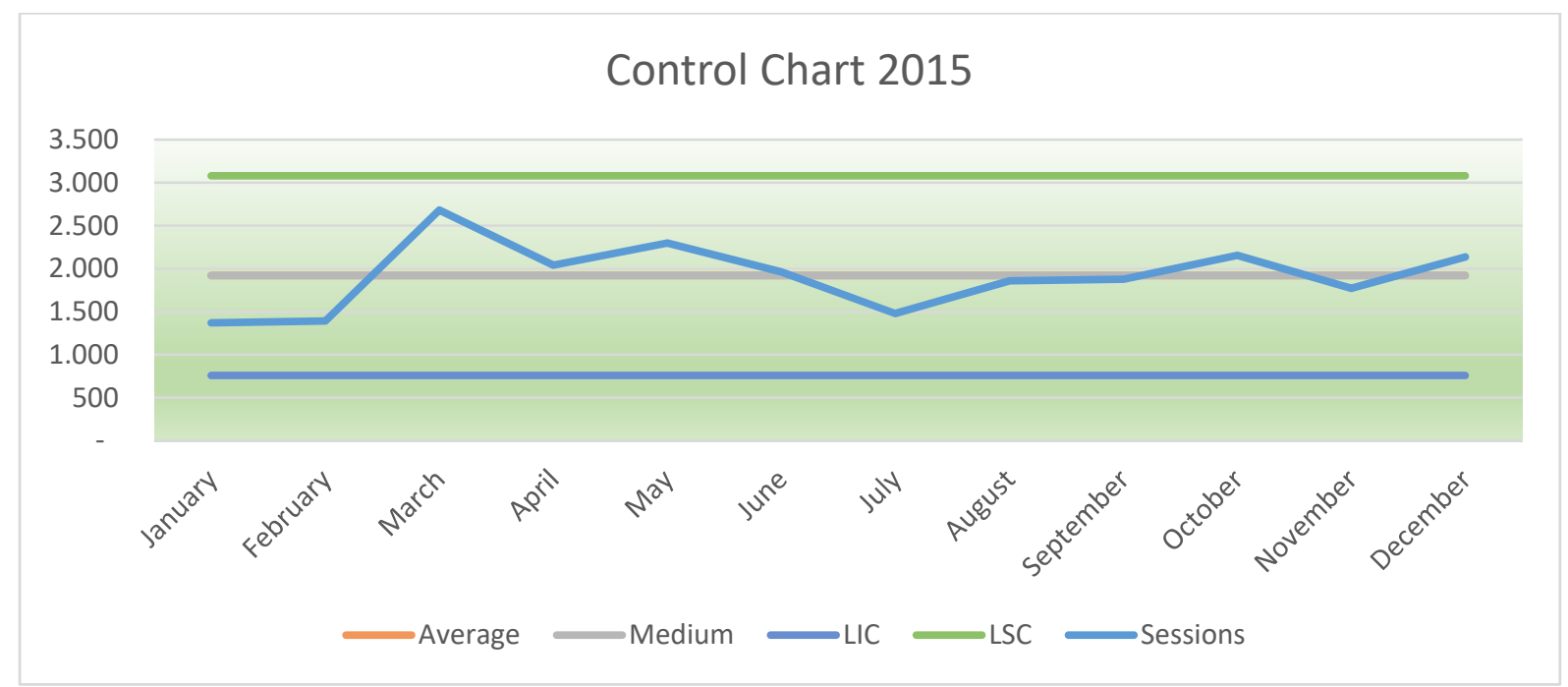

Figure 3: Control Graph of the sessions / accesses of the year 2015. Source: Authors (2019).

Figure 4 shows the control chart for the year 2016. It can be observed that the months of January, November and December had values that separated them from the mean and median values, and it can be observed that there was an inversion in the values between the mean and the median, where the mean exceeded the median. 


\section{Control Chart 2016}

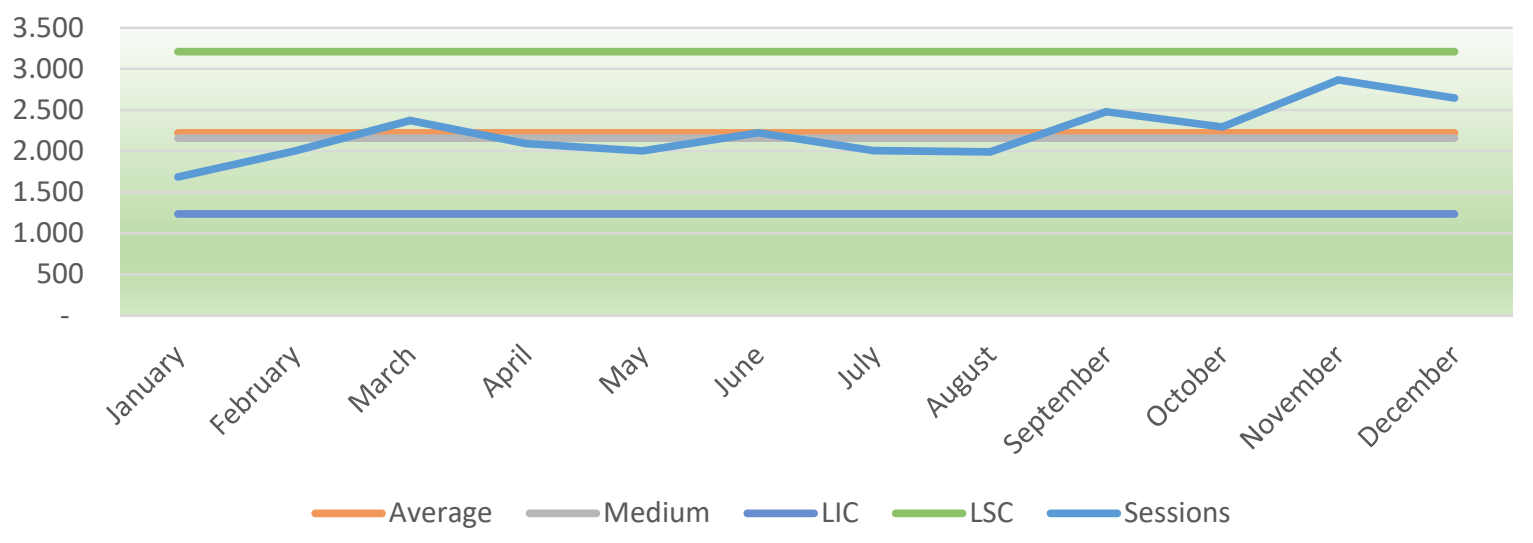

Figura 4: Gráfico de Controle das sessões/acessos do ano de 2016. Fonte: Autores (2019).

Figure 5 shows a result in which most months were close to the mean and median. There is an exSPCtion with respect to the months of January, March and November that had an average higher than the median, but with close values.

\section{Control Chart 2017}

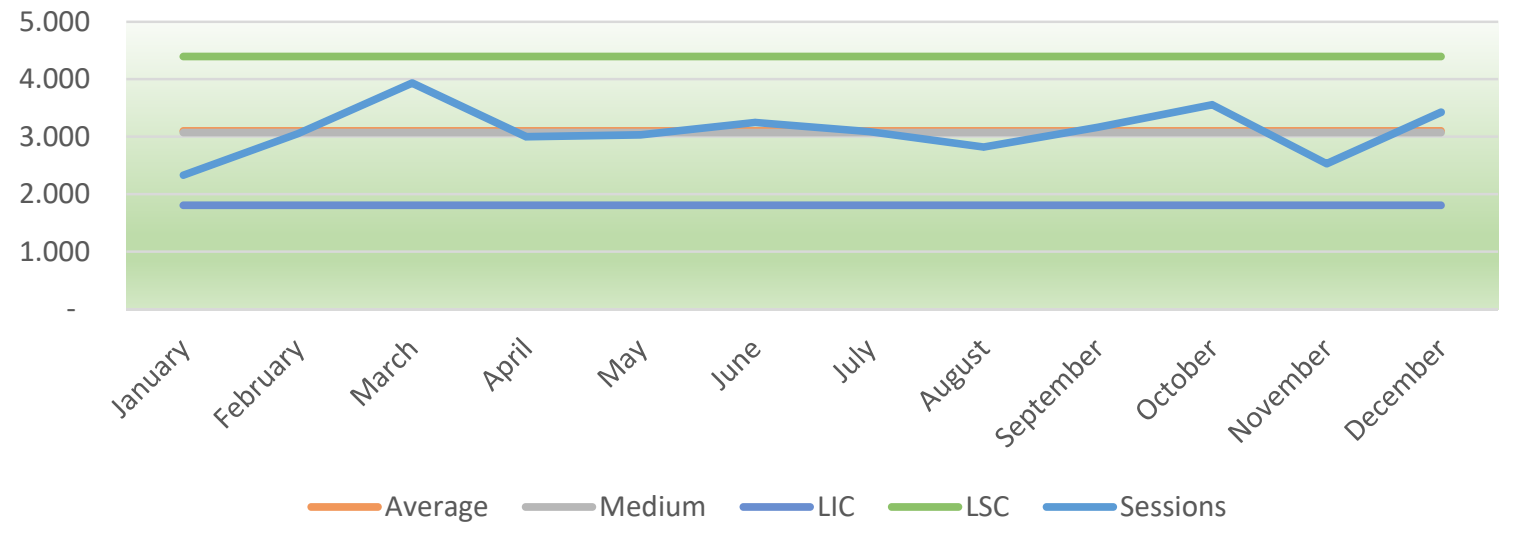

Figure 5: Control Graph of the sessions / accesses of the year 2017. Source: Authors (2019).

Figure 6 shows the result that January and February were below average and from September to December were above average, in which the month of October reached its apex. 


\section{Control Chart 2018}
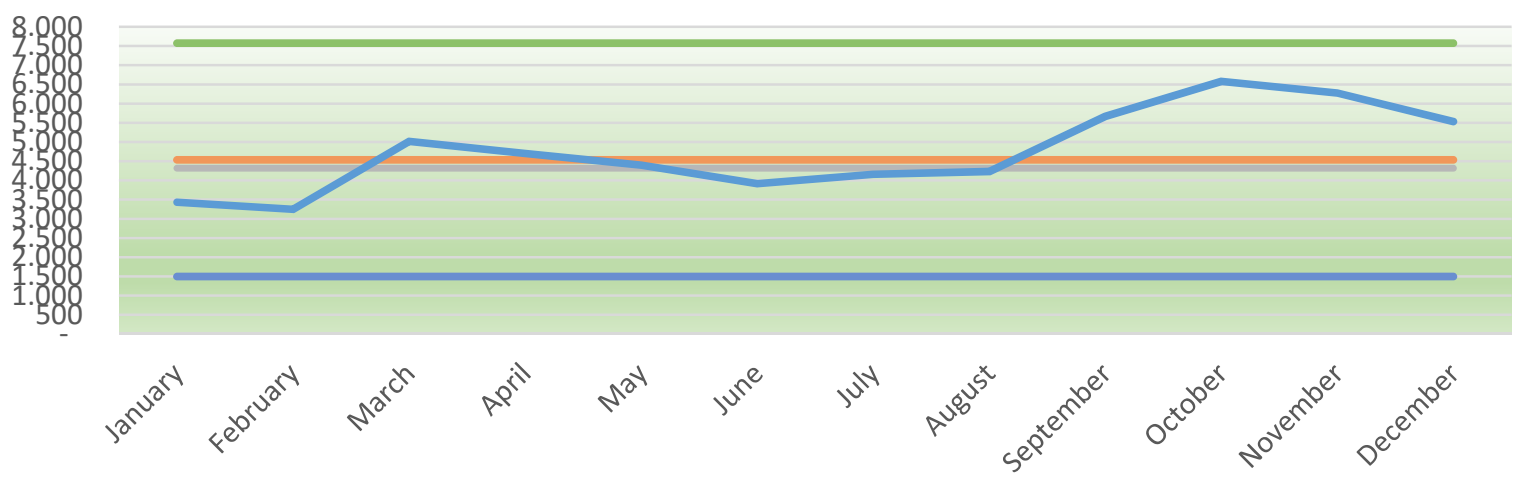

$\longrightarrow$ Average $\longrightarrow$ Medium $\longrightarrow$ LIC $\longrightarrow$ LSC $\longrightarrow$ Sessions

Figure 6: Control Graph of the sessions / accesses of the year 2017.

Source: Authors (2019).

In Table 5 is the result that was based on the sessions / accesses reported in previously in Table 3, so that some statistical details about the evolution of the journal can be observed.

Table 5: Information on the distribution of data over the last 60 months.

\begin{tabular}{lr}
\hline Total records & $\mathbf{6 0}$ \\
\hline Overall average & 2.691 \\
\hline Inferior limit & -93 \\
\hline Upper limit & 5.475 \\
\hline Amplitude & 5.568 \\
\hline Standard deviation (s) & 927,9872 \\
\hline Frequency & 8 \\
\hline \multicolumn{2}{c}{ Source: Authors (2019). }
\end{tabular}

In Table 6, the visualization histogram is shown, in which the frequency of occurrence can be observed for the number of visualizations that occurred during the 60 months.

Table 6: Histogram of visualizations between the years 2014 and 2018.

\begin{tabular}{|c|c|c|c|c|c|c|}
\hline \multicolumn{7}{|c|}{ Histogram of views } \\
\hline \multicolumn{3}{|c|}{ Views } & $\mathbf{X i}$ & Freq. & Summation & $\%$ \\
\hline 975 & |--- & 1797 & 1386 & 16 & 16 & $26,67 \%$ \\
\hline 1797 & |--- & 2619 & 2208 & 19 & 35 & $31,67 \%$ \\
\hline 2619 & |--- & 3441 & 3030 & 13 & 48 & $21,67 \%$ \\
\hline 3441 & |--- & 4263 & 3852 & 5 & 53 & $8,33 \%$ \\
\hline 4263 & |-- & 5085 & 4674 & 3 & 56 & $5,00 \%$ \\
\hline 5085 & |--- & 5907 & 5496 & 2 & 58 & $3,33 \%$ \\
\hline 5907 & |--- & 6729 & 6318 & 2 & 60 & $3,33 \%$ \\
\hline 6729 & |--- & 7551 & 7140 & 0 & 60 & $0,00 \%$ \\
\hline \multicolumn{3}{|c|}{ Total } & & 60 & & $100 \%$ \\
\hline
\end{tabular}


Source: Authors (2019).

Figure 7 shows the graph for the histogram of the views based on Tables 5 and 6 as a way to illustrate the results obtained with the analysis of the data.

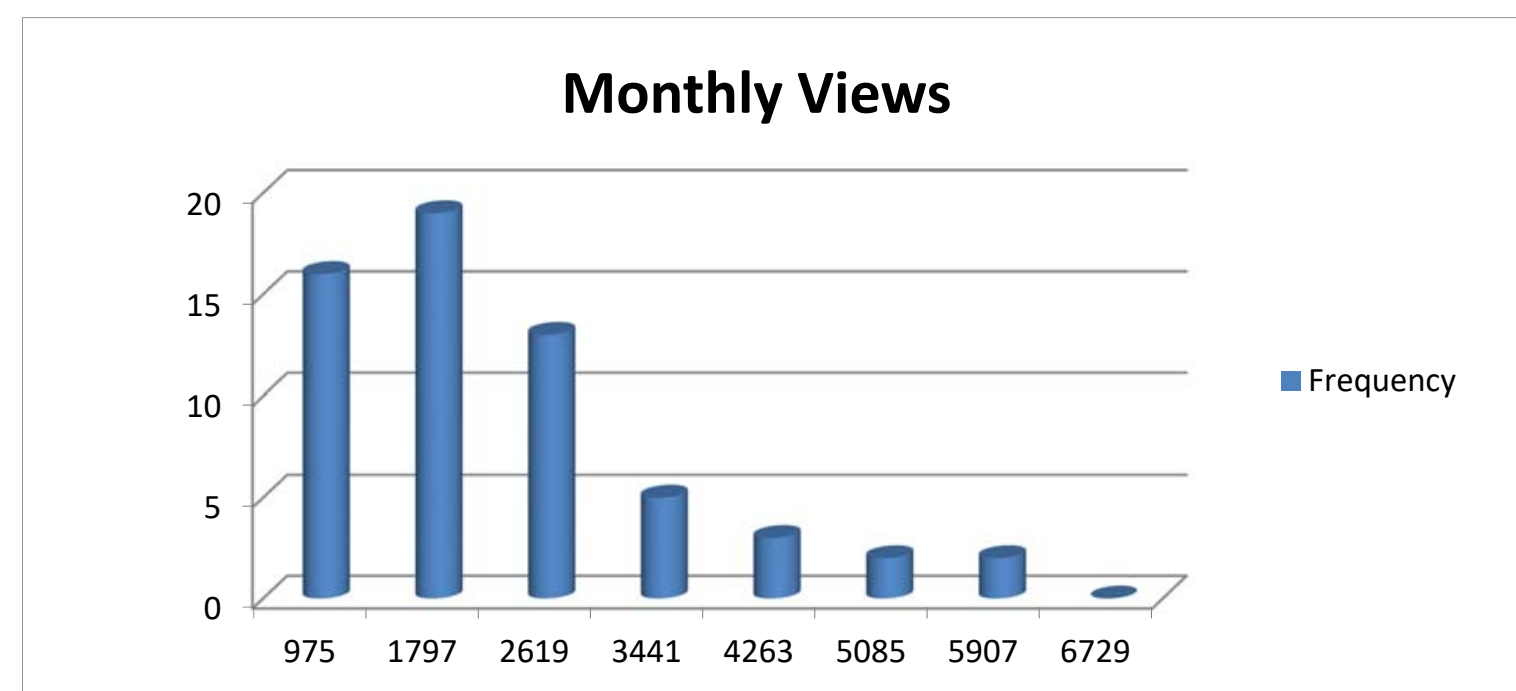

Figure 7: Histogram of the visualizations that occurred between the years 2014 and 2018.

Source: Authors (2019).

From Table 6 and Figure 7, it can be seen that the frequency between 1797 and 2619 was the one that occurred the most during the five years analyzed, representing $31.67 \%$ of the occurrences. However, in observing Table 3 , it can be seen that the tendency is that occurrences with values above 4,000 points increase, since in 2018 the lowest value was 3,247. In Table 7, the histogram of the average daily views is presented, in which the frequency of occurrence can be observed for the number of views.

Table 7: Histogram of average daily views between 2014 and 2018.

\begin{tabular}{|c|c|c|c|c|c|c|}
\hline \multicolumn{7}{|c|}{ Histogram of views } \\
\hline \multicolumn{3}{|c|}{ Views } & \multirow{2}{*}{$\frac{X i}{44,71}$} & \multirow{2}{*}{$\begin{array}{c}\text { Freq. } \\
14\end{array}$} & \multirow{2}{*}{$\begin{array}{c}\text { Summation } \\
14\end{array}$} & \multirow{2}{*}{$\begin{array}{c}\% \\
23,33 \%\end{array}$} \\
\hline 31,45 & |-- & 57,98 & & & & \\
\hline 57,98 & |-- & 84,50 & 71,24 & 21 & 35 & $35,00 \%$ \\
\hline 84,50 & |-- & 111,02 & 97,76 & 12 & 47 & $20,00 \%$ \\
\hline 111,02 & |-- & 137,55 & 124,29 & 6 & 53 & $10,00 \%$ \\
\hline 137,55 & |-- & 164,07 & 150,81 & 3 & 56 & $5,00 \%$ \\
\hline 164,07 & |-- & 190,60 & 177,33 & 2 & 58 & $3,33 \%$ \\
\hline 190,60 & |-- & 217,12 & 203,86 & 2 & 60 & $3,33 \%$ \\
\hline 217,12 & |-- & 243,65 & 230,38 & 0 & 60 & $0,00 \%$ \\
\hline \multicolumn{3}{|c|}{ Total } & & 60 & & $100 \%$ \\
\hline
\end{tabular}


Figure 8 shows the graph for the histogram of the average daily views and which was based on Table 7 as a way to illustrate the results obtained with the analysis of the data.

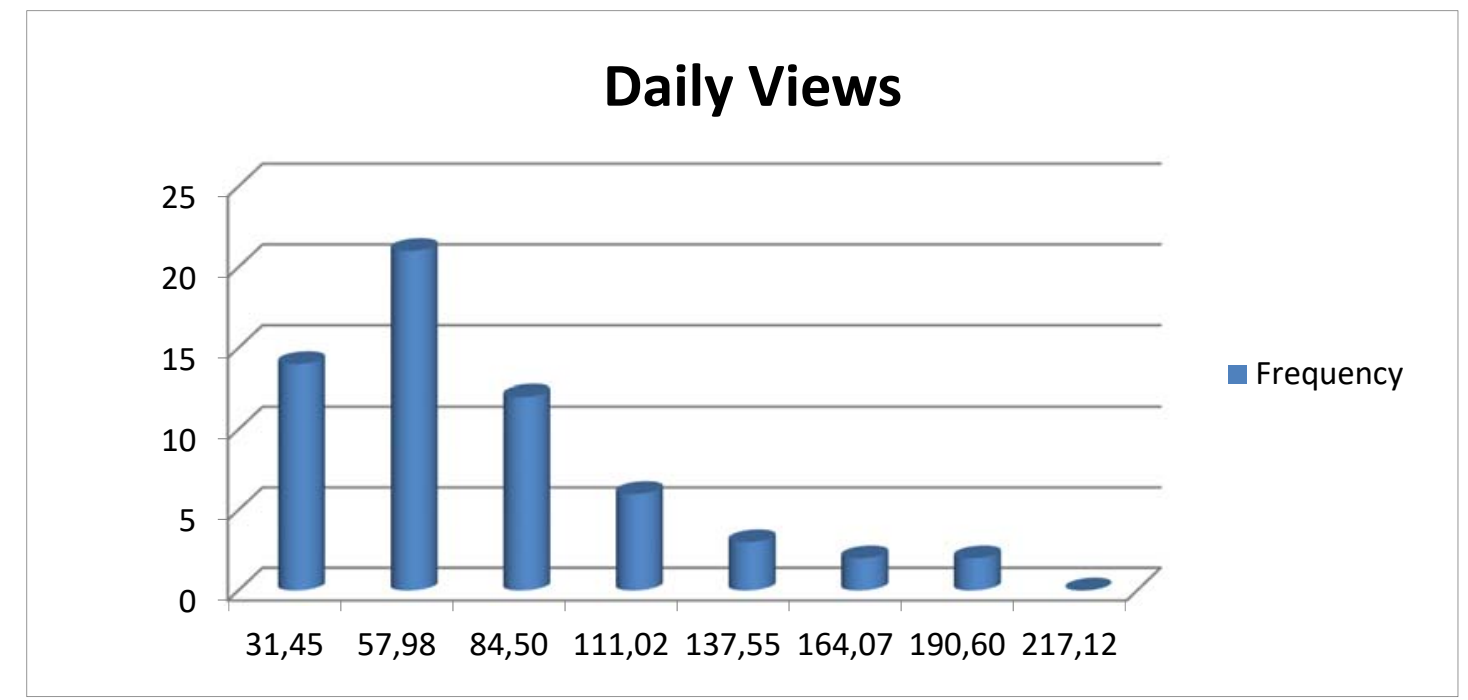

Figure 8: Histogram of the monthly views that occurred between the years 2014 and 2018.

Source: Authors (2019).

When analyzing the graph of Figure 9, we can see a variation in the results between the average monthly and daily frequencies. It should be noted that the graph was elaborated from Tables 6 and 7 . Allowing to conclude that even the monthly result having a higher occurrence does not necessarily reflect in the occurrences of the mean daily results.

\section{Histogram of views}

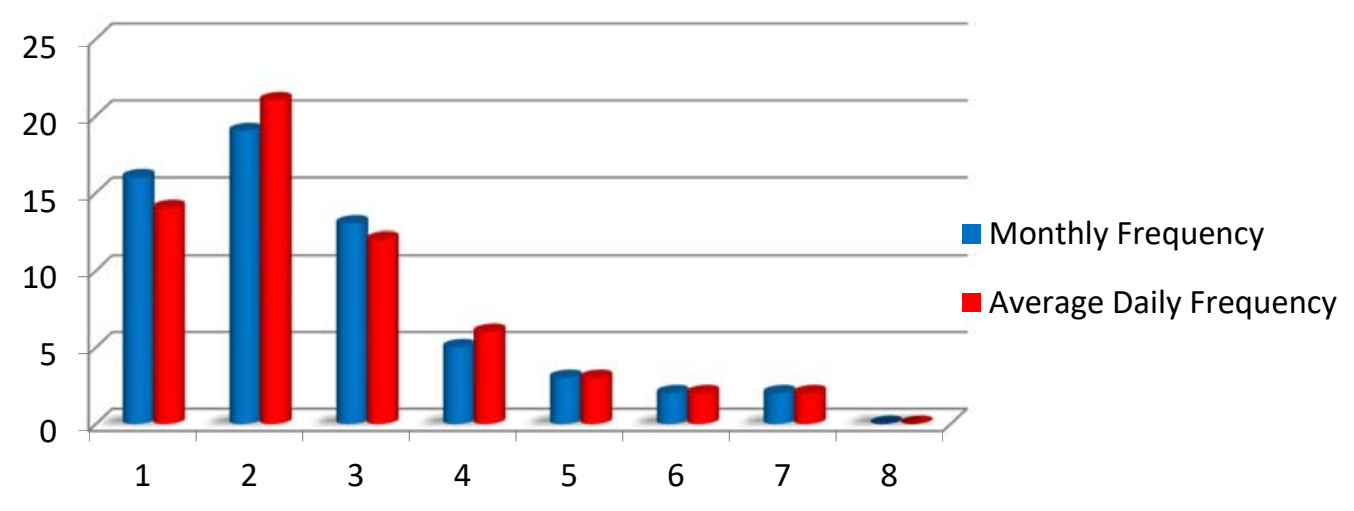

Figure 9: Comparative chart between the monthly and average daily frequencies. Source: Authors (2019).

It can be observed that the months with the lowest incidence of accesses varied according to the year. In 2014 the months that had a low index of access were: June, July and August. In the year of 2015 the months of January and February presented 
a low index of access, and the month of July was recurrent. In 2016, the months that presented a low access index were January, February and August, however, the months of February and August, had indexes close to 2,000 accesses. In 2017, access indexes were above 2,500 points, with the exSPCtion of January, which had an access index of 2,329 points.

In the year 2018, the access indexes were between 3,000 and 7,000 points, with the months of January and February being the months with the lowest access index and the months of October and November with the highest indexes and access, above 6,000 points.

When analyzing the results obtained in the year 2018, it is perceived that the trend of growth in views for the year 2019 should be approximately $15 \%$. Thus, the journal will contribute to a greater dissemination of tacit knowledge to the empirical and vice versa. As well as expanding its visualization and recognition at an international level. With the growth of access in the journal, there will be a greater visibility of the articles published on the web and, thus, an increase in the impact factor.

In the year 2018, the journal was indexed in the Web of Science database, which may have reflected in the increase of accesses and users. And by the year 2019, it is expected to achieve indexation in SCOPUS, which may lead to an increase in the number of accesses and users, the periodical will also stop being quarterly to be bimonthly.

To conclude, the evolutionary data of the Journal between the year of its creation (2010) and 2018 is presented in Table 8, allowing to observe how much the Journal has been growing, both with regard to the accesses and its visibility.

Table 8: Evolution of the Journal between 2010 and 2018.

\begin{tabular}{|l|c|c|c|c|c|c|}
\hline Year & Country & Cities & Access & Users & Viewers & Avg \\
\hline $\mathbf{2 0 1 0}$ & 25 & 75 & 340 & 181 & 5.474 & 456 \\
\hline $\mathbf{2 0 1 1}$ & 75 & 343 & 1.510 & 1.024 & 12.942 & 1.079 \\
\hline $\mathbf{2 0 1 2}$ & 83 & 444 & 2.187 & 1.406 & 15.499 & 1.292 \\
\hline $\mathbf{2 0 1 3}$ & 118 & 1.208 & 11.946 & 6.006 & 71.264 & 5.939 \\
\hline $\mathbf{2 0 1 4}$ & 146 & 1.978 & 17.440 & 10.503 & 68.340 & 5.695 \\
\hline $\mathbf{2 0 1 5}$ & 147 & 2.307 & 23.017 & 14.460 & 96.735 & 8.061 \\
\hline $\mathbf{2 0 1 6}$ & 162 & 2.911 & 26.654 & 17.847 & 112.928 & 9.411 \\
\hline $\mathbf{2 0 1 7}$ & 184 & 4.078 & 37.171 & 27.129 & 109.535 & 9.128 \\
\hline $\mathbf{2 0 1 8}$ & 190 & 5.220 & 57.157 & 44.400 & 187.729 & 15.644 \\
\hline
\end{tabular}

Source: Google (2019).

\section{FINAL CONSIDERATIONS}

The research presented a study of the accesses / sessions of the last 4 years of an international journal. From the analysis of the data, and with the use of the SPC 
tool, it was possible to construct graphs and histograms to understand the development and evolution of the journal. In addition, the work contributed to those who seek to better understand the stratification indexes of users with respect to their titration and gender.

From the presentation of the data of users of the international journal, it was verified that there is a growth in the number of visualizations in the last years, especially in the year of 2017. Considering an increase of approximately $20 \%$ in the visualizations in 2018, it is affirmed that the journal is providing researchers and stakeholders with free access to information that can be used in research. Thus, the authors who publish in the journal should gain more knowledge and their research visibility, so that science will develop faster and become more transparent.

As a limitation of the research, it is possible to say that, in relation to the data, only the data sessions / accesses and their daily average, between the years of 2014 and 2017 , were analyzed. We intend to analyze in this same temporary range joint data on the number of users who accessed the journal, as well as the number of pages viewed and their daily averages. Finally, the description of the results was focused and critical, structured, as far as possible, to expand knowledge about the characteristics of the international journal, given its relevance and relevance in academic research. There is no profusion of research on a cross-analysis between sessions / accesses and views, users and views and isolated studies of these variables; it is suggested to carry out future studies that deepen this field of knowledge in order to identify parameters that may contribute to improve the access and participation of the international journal among researchers.

\section{REFERENCES}

ARAUJO, C. G. S.; SARDINHA, A. (2011) Índice-H dos artigos citantes: uma contribuição para a avaliação da produção científica de pesquisadores experientes. Ver. Bras. Med. Esporte, v. 17, n. 5, p. 358-362.

ASADI, S. et al. (2017) Organizational research in the field of Green IT: A systematic literature review from 2007 to 2016 . Telematics and Informatics, v. 34, n. 7, p. 1191-1249.

CARNEIRO NETO, W. (2003) Controle estatístico de processo SPC. [CDROM]. Recife: UPE-POLI.

FIGUEIREDO, M. S. N.; PEREIRA, A. M. (2017) Managing Knowledge - The Importance of Databases in the Scientific Production. Procedia Manufacturing, $v$. 12, p. 166-173. DOI: 10.1016/j.promfg.2017.08.021 
FERREIRA, A. G. C.; CAREGNATO, S. E. (2008) A editoração eletrônica de revistas científicas brasileiras: o uso de SEER/OJS. Transinformação, v. 20, n. 2, p. 171180.

FETTBACK, E.; GIRON, E. C.; NETO, O. (2011) Direito sanitário no meio ambiente aplicado na segurança do alimento. In: PANASSOLO, A.; STEFANELLO, A. G. F.; BARACAT, F. A. P. (Org.). Direito ambiental nos 30 anos da Lei de Política Nacional do Meio Ambiente. Curitiba: Juruá.

GIL, A. C. (2009) Como elaborar projetos de pesquisa. 4. ed. 12. Reimpressão. São Paulo: Atlas.

GIRON, E.; OPAZO, M. A. U.; ROCHA JUNIOR, W. F.; GIMENES, R. M. T. (2013) Aplicação do controle estatístico de processo em uma empresa do setor avícola.

Revista de Administração e Inovação, São Paulo, v. 10, n. 4, p. 38-62.

IBICT. Revistas brasileiras que utilizam o SEER/OJS. Disponível em:<http://www.ibict.br/secao.php?cat=SEER/OJS/Revistas\%20Brasileiras $>$. Acesso em: 22/06/2018.

KUME, H. (1985) Métodos estatísticos para melhoria da qualidade. 11 ed. São Paulo: Editora Gente.

LIMA, A. A. N.; LIMA, J. R.; SILVA, J. L.; ALENCAR, J. R. B.; SOARES-SOBRINHO, J. L.; LIMA, L. G.; ROLIM-NETO, P. J. (2006) Aplicação do controle estatístico de processo na indústria farmacêutica. Revista de Ciências Farmacêuticas Básica e Aplicada, v. 27, n.3, p.177-187.

MARCONI, M. A.; LAKATOS, E. M. (2009) Metodologia do trabalho científico. 7. ed. 3. Reimpressão. São Paulo: Atlas.

MÁRDERO ARELLANO, M. A.; FERREIRA, S. M. S. P.; CAREGNATO, S. E. Editoração eletrônica de revistas científicas com suporte do protocolo OAI. In: FERREIRA, S. M. S. P.; TARGINI, M. D. G. Preparação de revistas científicas: teoria e prática. São Paulo: Reichmann \& Autores Editores, 2005.

MIGUEL, P. A. C. Metodologia de pesquisa em engenharia de produção e gestão de operações. Rio de Janeiro: Elsevier, 2010.

MCNUTT, M. (2014) The measure of research merit. Science, v. 346, n. 6214, p. 1155.

MONTGOMERY, D. C. (2004) Introdução ao controle estatístico da qualidade. 4. ed. Rio de Janeiro: LTC.

MONTOYA, F. G. et al. (2018) A fast method for identifying worldwide scientific collaborations using the Scopus database. Telematics and Informatics, v. 35, n. 1, p. 168-185.

MOREIRA, D. A. (2004) Administração da produção e operações. São Paulo: Pioneira.

NOMELINI, Q. S. S.; FERREIRA, E. B.; OLIVEIRA, M. S. (2009) Estudos dos padrões de não aleatoriedade dos gráficos de controle de Shewhart: um enfoque probabilístico. Revista Gestão \& Produção, São Carlos, v. 16, n. 3. DOI: 10.1590/S0104-530X2009000300008.

OLIVEIRA, M. C. Análise dos periódicos Brasileiros de contabilidade. Rev. contab. finanç., v.13, n. 29, 2002. DOI: 10.1590/S1519-70772002000200005 
PAVLOVSKIY, I. S. (2017) Using ConSPCts of Scientific Activity for Semantic Integration of Publications. Procedia Computer Science, v. 103, p. 370-377. DOI: 10.1016/j.procs.2017.01.123

RAVISHANKAR, M. N. (2013) Public ICT innovations: a strategic ambiguity perspective. Journal of Information Technology, v. 28, n. 4, p. 316-332.

SANTOS, G. A.; LACERDA, E. F.; ALBUQUERQUE NETO, H. C.; LUNE, W. A; FURLANETTO, E. L. (2010) A importância dos gráficos de controle para monitorar a qualidade dos processos industriais: Estudo de caso numa indústria metalúrgica. Revista Cadernos do IME - Série Estatística, v. 28, p. 33-46.

TOLEDO, J. C.; BATALHA, M. O.; AMARAL, D. C. (2000) Qualidade agroalimentar: situação atual e perspectivas. Revista de Administração de Empresas, v. 40, n. 2, p. 90-101.

VACCARO, G. L. R.; MARTINS, J. C.; MENEZES, T. M. (2011) Análise estatística da qualidade de níveis de tensão em sistemas de distribuição de energia elétrica. Revista Produção, v. 21, n. 3. DOI: 10.1590/S0103-65132011005000047

VILAS BOAS, E. B. (2005) Estudo da qualidade da matéria-prima de uma fábrica de ração para frangos de corte utilizando cartas de controle e técnicas de Taguchi de custo médio. Dissertação de Mestrado em Desenvolvimento Regional e Agronegócio - Universidade Estadual do Oeste do Paraná, Toledo.

YIN, R. K. (2005) Estudo de caso: planejamento e métodos. 3 ed. Porto Alegre: Bookman. 